\title{
Effect of Ti Addition to Age Hardening Response of Al-10Zn-6Mg- xTi Alloy Produced by Squeeze Casting
}

\author{
Dwi Ayu Nurcahyaningsih ${ }^{1}$, Risly Wijanarko ${ }^{1}$, Irene Angela ${ }^{1}$, and Bondan Tiara Sofyan ${ }^{1}$ \\ ${ }^{1}$ Department of Metallurgy and Materials Engineering, Faculty of Engineering, Universitas of Indonesia, Depok 16424, West Java, \\ Indonesia
}

\begin{abstract}
This research focused on investigating the effects of Ti addition on the age hardening response of Al 7xxx alloy for Organic Rankine Cycle (ORC) turbine impeller application in power plant generators. Al-10Zn-6Mg wt. \% alloys were produced by squeeze casting with $0.02,0.05$, and 0.25 wt. $\%$ Ti addition. As-cast samples were homogenized at $400{ }^{\circ} \mathrm{C}$ for $4 \mathrm{~h}$. Solution treatment was conducted at $440{ }^{\circ} \mathrm{C}$ for $1 \mathrm{~h}$, followed by quenching and ageing at $130{ }^{\circ} \mathrm{C}$ for $200 \mathrm{~h}$. Age hardening result was observed using Rockwell B hardness measurement. Other characterizations included impact testing, STA, optical microscopy, and SEM-EDS. Results showed that the addition of $\mathrm{Ti}$ in all content variations increased the as-cast hardness due to the diminution of secondary dendrite arm spacing (SDAS) values of the alloy. Ageing at $130{ }^{\circ} \mathrm{C}$ strengthened the alloys, however the addition of Ti was not found to affect neither peak hardness nor impact values of the alloy. Identities of second phases formed during solidification were found to be $\mathrm{T}$ $\left(\mathrm{Mg}_{32}(\mathrm{Al}, \mathrm{Zn})_{49}\right), \beta\left(\mathrm{Al}_{8} \mathrm{Mg}_{5}\right)$, and $\mathrm{TiAl}_{3}$, while precipitates produced during ageing were GP Zone, $\eta$, and $\eta$ $\left(\mathrm{MgZn}_{2}\right)$. Keywords - ageing, $\mathrm{Al}-\mathrm{Zn}-\mathrm{Mg}$, grain refining, $\mathrm{MgZn}_{2}$, Ti addition.
\end{abstract}

\section{Introduction}

Al 7xxx alloys with its $\mathrm{Zn}$ and $\mathrm{Mg}$ alloying content are commonly used for high temperature service. The alloy is currently developed for turbine impeller application in novel Organic Rankine Cycle/ORC power generating system considering its lightweight, strong, and durable properties [1] that would contribute positively to the overall system efficiency.

Grain refining agents - e.g. $\mathrm{Ti}, \mathrm{Cr}, \mathrm{Zr}$, or other rare earth elements are used in order to further strengthen the alloy. Kurniawan [2] founded that 0.067, 0.081, and 0.115 wt. $\%$ Ti content in AC4B alloy all resulted in increased strength and UTS value of the alloy. Addition of 0.050 and 0.072 wt. $\%$ Ti was also evident to be able to optimize the hardness of AC4B alloy by $2.80 \%$ and $7.17 \%$, along with optimizing its tensile strength by $4.40 \%$ and $5.10 \%$ compared to those without $\mathrm{Ti}$ addition. The strengthening mechanism was a result of primary $\alpha-\mathrm{Al}$ grain refining phenomenon followed by a decrease in dendrite arm spacing/DAS value [3]. Heterogeneous nucleation and grain boundary strengthening effect were also found after $0.058,0.073$, and 0.104 wt. $\% \mathrm{Ti}$ addition to both squeeze-cast and aged Al-9Zn-6Mg-2Si wt. \% alloy with $\mathrm{ZrO}_{2}$ reinforcement [4].

Sigworth and Kuhn [5] showed that Ti contributed to the grain refining mechanism by rising $\mathrm{Al}$ solidification temperature from 660.1 to $665{ }^{\circ} \mathrm{C}$, at which $\mathrm{TiAl}_{3}$ particles formed and initiated the cooling of $\mathrm{Al}$ melt to primary $\alpha$-Al phase. $\mathrm{TiAl}_{3}$ particles induced a heterogeneous nucleation of $\alpha$-Al, hence a greater number of present $\mathrm{TiAl}_{3}$ would refine the overall grain size. A research by Gao, et. al. [6] displayed an agreement to the statement, in which the addition of 0.2 wt. \% Ti to Al-6Zn-2Mg-2Cu- $0.2 \mathrm{Zr}$ wt. \% alloy resulted in smaller $\alpha$-Al grains in comparison to alloy samples without Ti addition. This is, however, limited to a certain time range during the cooling process before a fading event - submerging $\mathrm{TiAl}_{3}$ intermetallic particles to the bottom of crucibles due to a prolonged holding time occurs. On the occasion where intermetallic nuclei were unable to form, Ti would serve as a growth restricting agent [7]. The grain refining effect, by all mechanisms, will result in higher strength of the Al-alloy in accordance to Hall-Petch equation.

Further strengthening of $\mathrm{Al} 7 \mathrm{xxx}$ alloy is generally done through age hardening/T6 heat treatment method which consists of solution treatment, quenching, and ageing steps, producing precipitates of new phases that render dislocation movement. Possible identities of formed phases include GP Zone [8], $\eta\left(\mathrm{MgZn}_{2}\right), \eta$ ' [9], $\beta ”, \mathrm{MgSi}_{2} \quad[10]$, cubic T' $\left(\mathrm{Mg}_{32}(\mathrm{Al}, \mathrm{Zn})_{49}\right)$, and equilibrium $\mathrm{T}$ [11]. Reportedly, the addition of $\mathrm{Ti}$ was able to accelerate the precipitation forming in experimental ageing of $\mathrm{Al}-6 \mathrm{Zn}-2 \mathrm{Mg}-2.5 \mathrm{Cu}-0.2 \mathrm{Zr}-0.2 \mathrm{Ti}$ wt. $\%$ at $120{ }^{\circ} \mathrm{C}$ [6] and prevent grain boundary segregation from occurring during air cooling [9].

The above literature survey shows contributions of $\mathrm{Ti}$ alloying element to both as-cast and after age hardening properties of $\mathrm{Al} 7 \mathrm{xxx}$ alloy. Thus, the present work attempts to analyze the effects of Ti addition at varying 
contents to the microstructure and mechanical properties of as-cast and age-hardened AlZnMg alloy.

\section{Experimental methods}

Al-10Zn-6Mg wt. \% base alloys were produced using commercial pure Al (99.79 wt. \%), Zn (99.99 wt. \%), and $\mathrm{Mg}$ (99.90 wt. \%) ingots with additions of Al-5Ti-B masteralloy rods at varying amounts to obtain final $\mathrm{Ti}$ content of $0.02,0.05$, and 0.25 wt. $\%$. Starting materials were melted in a crucible furnace at $850{ }^{\circ} \mathrm{C}$, degassed using argon gas for $1 \mathrm{~min}$, and stirred immediately for 2 min. The melts were poured into a $170 \times 170 \times 15 \mathrm{~mm}^{3}$ preheated metal mould followed with squeeze casting at $76 \mathrm{MPa}$ for $10 \mathrm{~min}$. Homogenisation was done at $400{ }^{\circ} \mathrm{C}$ for $4 \mathrm{~h}$ to uniform the microstructure of as-cast samples. Chemical composition of the Al-alloys determined by OES analysis using ARL 3460 OE Spectrometer is presented in Table 1. The alloys were then heat treated by T6 procedure consisting of solution treatment at 440 ${ }^{\circ} \mathrm{C}$ for $1 \mathrm{~h}$ followed with water quenching and ageing at $130{ }^{\circ} \mathrm{C}$ for $2-200 \mathrm{~h}$. Samples for mechanical testing, microstructure, and phase characterizations were machined to prescribed test specifications.

Table 1. Chemical composition of as-homogenized Al-10Zn$6 \mathrm{Mg}$-xTi wt. \% alloys.

\begin{tabular}{clcccc}
\hline Sample & \multicolumn{1}{|l}{ Zn } & $\mathbf{M g}$ & $\mathbf{T i}$ & $\mathbf{F e}$ & Al \\
\hline A & 10.318 & 6.741 & 0.004 & 0.172 & bal. \\
B & 9.701 & 6.734 & $0.018-0.0204$ & 0.235 & bal. \\
C & 11.116 & 7.127 & $0.048-0.067$ & 0.268 & bal. \\
D & 9.227 & 6.835 & $0.249-0.299$ & 0.226 & bal. \\
\hline
\end{tabular}

Mechanical testing was done through ASTM E 18 Rockwell B hardness testing and Charpy impact testing method. Zeiss-Primotech optical microscope and Zeiss SEM-EDS instrument were used for microstructural investigation on specimens prepared with standard metallographic preparation using $0.5 \% \mathrm{HF}$ etchant. Calculation of SDAS values were done on microstructure image of as-cast sample at $50 \mathrm{x}$ magnification using ImagePro Analysis. Simultaneous Thermal Analysis (STA) was conducted to observe phase transformations, heat fluctuations, and alloys crystallinity as a function of time on temperatures on ashomogenized samples using STA 6000 Parkin Elmer at $30-750{ }^{\circ} \mathrm{C}$ with $10{ }^{\circ} \mathrm{C} / \mathrm{min}$ scanning rate in accordance to ASTM E 168 standard.

\section{Results and discussion}

\subsection{As-cast microstructures and hardness}

Figure 1 presents the microstructures of $\mathrm{Al}-10 \mathrm{Zn}-6 \mathrm{Mg}$ alloys with various addition of Ti. Dendrites size decreased along with increasing content of $\mathrm{Ti}$ up to 0.25 wt. \%. Microstructure of all samples, however, showed porosities occurring due to the existence of dissolved gas in the melting process. Eutectic phase $\beta\left(\mathrm{Al}_{8} \mathrm{Mg}_{5}\right)$ was observed clearly inside the interdendritic phase. This is in agreement with the solidification sequence by
Raghafan [12] which figured that $\mathrm{Al}-10 \mathrm{Zn}-6 \mathrm{Mg}$ alloy would form $\mathrm{L}+\mathrm{T}$ at $480{ }^{\circ} \mathrm{C}$ and $\beta$ at $448{ }^{\circ} \mathrm{C}$, subsequently.
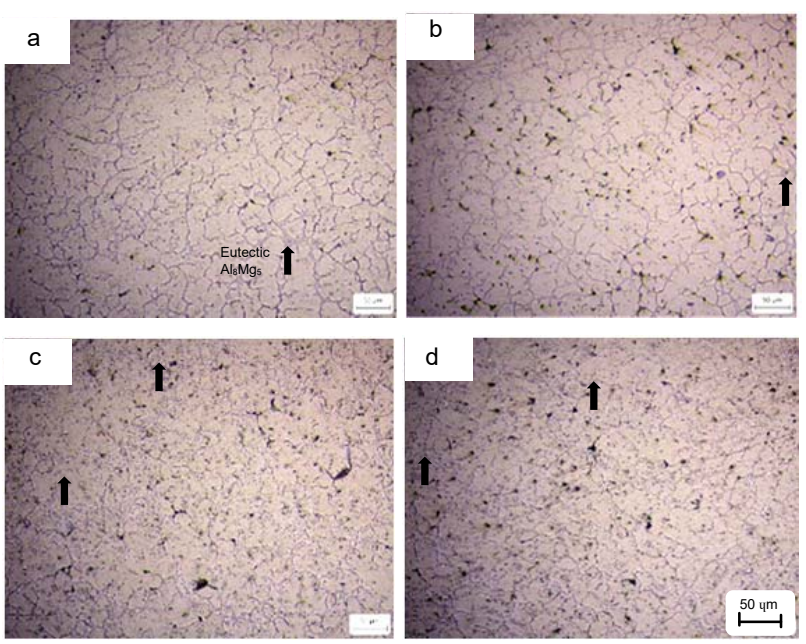

Fig. 1. Microstructure of as-cast $\mathrm{Al}-10 \mathrm{Zn}-6 \mathrm{Mg}$ alloy with : (a) 0 , (b) 0.02 , (c) 0.05 , and (d) 0.25 wt. $\% \mathrm{Ti}$.

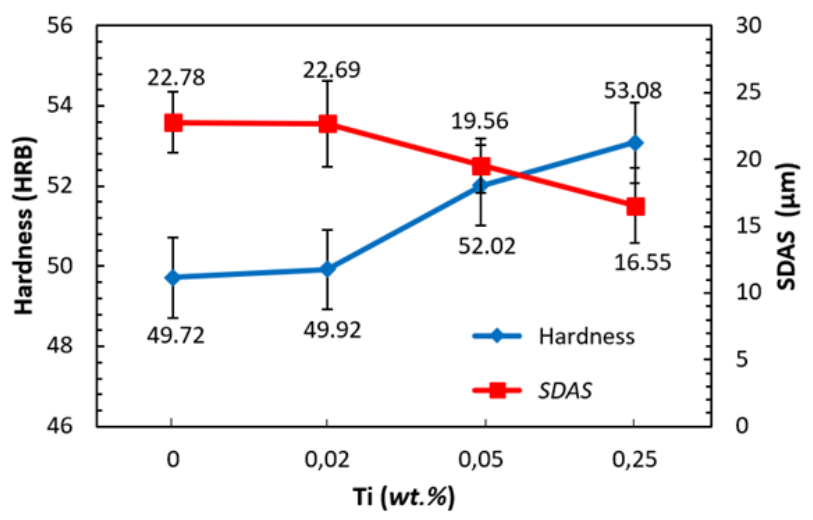

Fig. 2. The effect of Ti addition on hardness values and SDAS on $\mathrm{Al}-10 \mathrm{Zn}-6 \mathrm{Mg}-\mathrm{xTi}$ alloys.

Ti addition affected the hardness and dendrites size of the alloy, as seen in Figure 2. As the addition of $\mathrm{Ti}$ increased, the SDAS values decreased while hardness of the alloy improved. Obtained SDAS values were 22.78, $22.69,19.56$, and $16.55 \mu \mathrm{m}$ for the addition of $0,0.02$, 0.05 , and $0.25 \mathrm{wt}$ \% $\mathrm{Ti}$, respectively. The hardness value increased gradually from $49.72 \mathrm{HRB}$ to 49.92 , 52.02, and 53.08 HRB, respectively for each Ti addition. Both results are related to each other. The addition of grain refiner promoted grain boundaries strengthening, thus improving the mechanical properties $[3,4]$. Grain refining action of $\mathrm{Ti}$ was achieved by the forming and distribution of $\mathrm{TiAl}_{3}$ intermetallic phase in the melt, which became the nucleating place for $\alpha$-Al. Another mechanism to note was the increasing of Growth Restriction Factor (GRF) due to the presence of solute Ti. The GRF value of the alloy escalated from 21 to $25.91,33.28$, and 82.4 at the addition of $0.02,0.05$, and 0.25 wt. \% Ti respectively. Therefore, it can be inferred that grain refinement mechanisms of $\mathrm{Ti}$ in this alloy were $\alpha$-Al nucleation and GRF escalation. 


\subsection{Effect of Ti on age hardening mechanism}

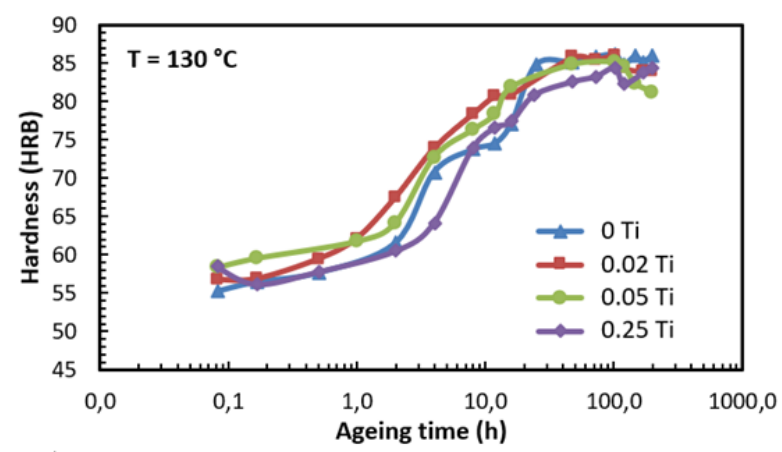

Fig. 3. Age hardening response of Al-10Zn-6Mg-xTi alloys at $130{ }^{\circ} \mathrm{C}$ for $200 \mathrm{~h}$.

Age hardening response was observed in underaged, peakaged, and overaged conditions, of which hardness values can be seen in Figure 3. In the first $5 \mathrm{~min}$, the alloys possessed underaged condition with hardness values of 55.3, 56.8, 58.3, and 58.4 $\mathrm{HRB}$ at addition of 0 , $0.02,0.05$, and 0.25 wt. $\% \mathrm{Ti}$, respectively. Ti-doped alloys showed higher hardness values than those without. This is similar to a research by Gao, et. al. [6] which found that the presence of $\mathrm{Ti}$ accelerated initial ageing stage during artificial ageing at $120{ }^{\circ} \mathrm{C}$, furthermore improved the hardness value. Peak ageing was observed at $102 \mathrm{~h}$ when hardness values of all samples significantly increased. However, sample without $\mathrm{Ti}$ addition showed higher hardness than Ti-added alloys. Alloys with $0,0.02,0.05$, and 0.25 wt. $\% \mathrm{Ti}$ had hardness values of 86.1, 85.9, 85.1, and 84.4 HRB, respectively. Moreover, the hardness values seemed to decrease as the Ti content was increasing. Therefore, it can be concluded that Ti did not induce either second phase or intermetallic phase formation at peakaged condition.

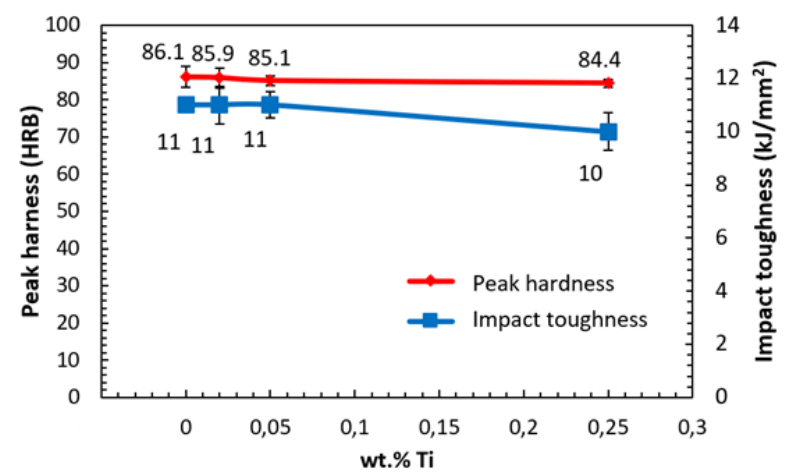

Fig. 4. Peak hardness and impact toughness values of Al-10Zn$6 \mathrm{Mg}-\mathrm{xTi}$ at $130{ }^{\circ} \mathrm{C}$.

Figure 4 illustrates the effect of $0,0.02,0.05$, and 0.25 wt. $\%$ Ti addition on impact toughness and peak hardness of $\mathrm{Al}-10 \mathrm{Zn}-6 \mathrm{Mg}$. It can be inferred that peak hardness and impact toughness were seemingly equal on all $\mathrm{Ti}$ variations; hence the addition of Ti contributed no significant effect on both aspects at peakaged condition. High level of hardness values at peakaged condition were a result of the formation of semi-coherent $\eta$ '
$\mathrm{MgZn}_{2}$ precipitates in $\alpha$-Al matrix. The precipitates distributed uniformly in the alloy during ageing furthermore inhibited dislocation movement due to deformation forces applied and improved the hardness value. Meanwhile, the addition of Ti, which contributed on reducing SDAS values, performed no effect on peak hardness. Instead, the formation of precipitates itself which took a big role on improving the mechanical properties. The images of fracture surface for each alloy with various Ti addition are shown in Figure 5. Fracture surface of alloys in as-aged condition were generally identified as brittle fracture. The images also show different grain fineness, where alloys with higher $\mathrm{Ti}$ content had finer grains.
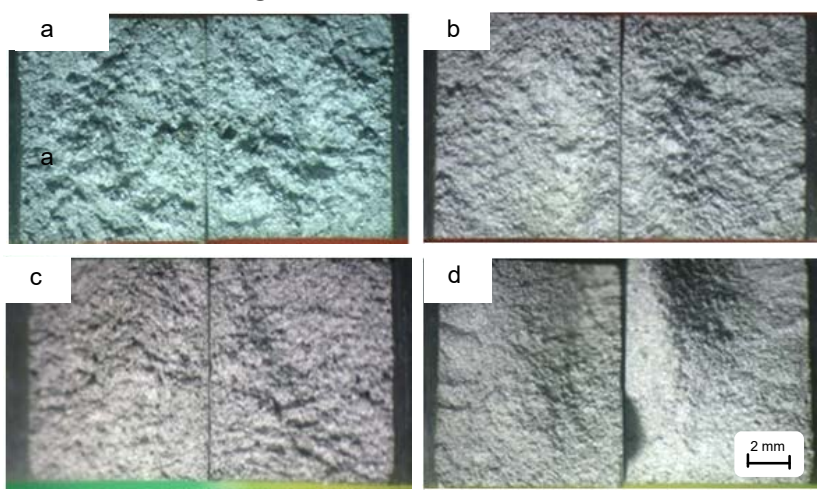

Fig. 5. Fracture surface of $\mathrm{Al}-10 \mathrm{Zn}-6 \mathrm{Mg}$ with addition of (a) 0 , (b) 0.02 , (c) 0.05 , and (d) 0.25 wt. $\%$ Ti.

Microstructures of $\mathrm{Al}-10 \mathrm{Zn}-6 \mathrm{Mg}-\mathrm{xTi}$ are shown in Figure 6. Interdendritic phase in white contrast and porosities in black contrast were observed in the structures. The number of interdendritic phase increased with more Ti addition. Porosities were formed due to the dissolution of hydrogen gas during casting process.

\subsection{Phase transformation analysis with SEM/EDS}

Figure 7 and Table 2 present the SEM images and EDX data of Al-10Zn-6Mg-xTi at peakaged condition. $\alpha-\mathrm{Al}$ matrix, $\mathrm{T}\left(\mathrm{Mg}_{32}(\mathrm{Al}, \mathrm{Zn})_{49}\right)$, and $\beta\left(\mathrm{Al}_{8} \mathrm{Mg}_{5}\right)$ were detected in Figure 7 (a-d). T phase was observed in cubic shape due to a low ratio of $\mathrm{Zn}: \mathrm{Mg}$. Interestingly, point 12 shows spider web-shaped cubic $\beta$ phase inside the interdendritic structure. $\mathrm{T}$ and $\beta$ phases were formed during the initial process of solidification. The low ratio of $\mathrm{Zn}: \mathrm{Mg}$ caused $\eta\left(\mathrm{MgZn}_{2}\right)$ phase to be undetected in all alloy compositions. $\mathrm{TiAl}_{3}$ was supposed to form in nanoparticle size that the morphology could not be observed. $\mathrm{C}$ and $\mathrm{O}_{2}$ content was found in the alloy due to residual Al-SiC polishing cloth and paste $\left(\mathrm{Al}_{2} \mathrm{O}_{3}\right)$.

\subsection{Phase transformation analysis with STA}

Phase transformation of the alloys can be seen through the endothermic and exothermic peak in Figure 8 (a-d). Reaction occurring in Al-10Zn-6Mg-xTi was SSSS $\rightarrow$ GP zone $\rightarrow \eta^{\prime} \rightarrow \eta$ [13]. Table 3 shows the formation (exothermic) and diffusion (endothermic) temperatures 
of the alloys due to the heating process. Khrisna, et. al. [13] observed that the GP zone, $\eta$ ', and $\eta$ developed at 20-120 ${ }^{\circ} \mathrm{C}, 120-150{ }^{\circ} \mathrm{C}$, and $150-300{ }^{\circ} \mathrm{C}$, respectively, while diffusion of each phases took place at $50-150{ }^{\circ} \mathrm{C}$, $200-250{ }^{\circ} \mathrm{C}$, and $300-350{ }^{\circ} \mathrm{C}$, respectively, which are appropriate with findings in this work.
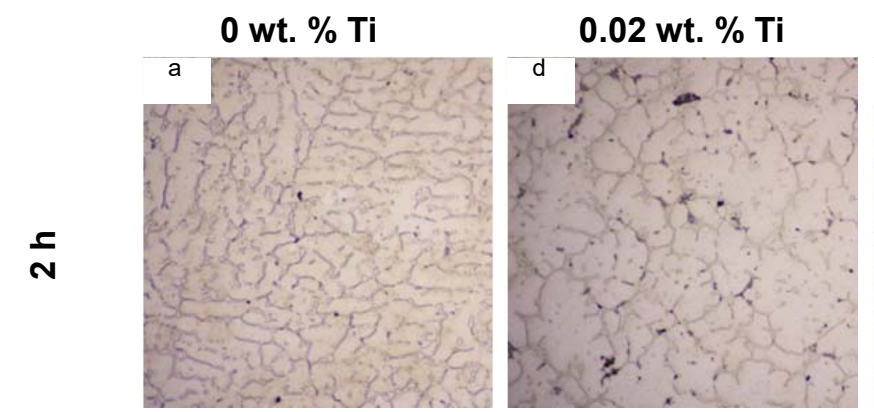

0.05 wt. $\% \mathrm{Ti}$
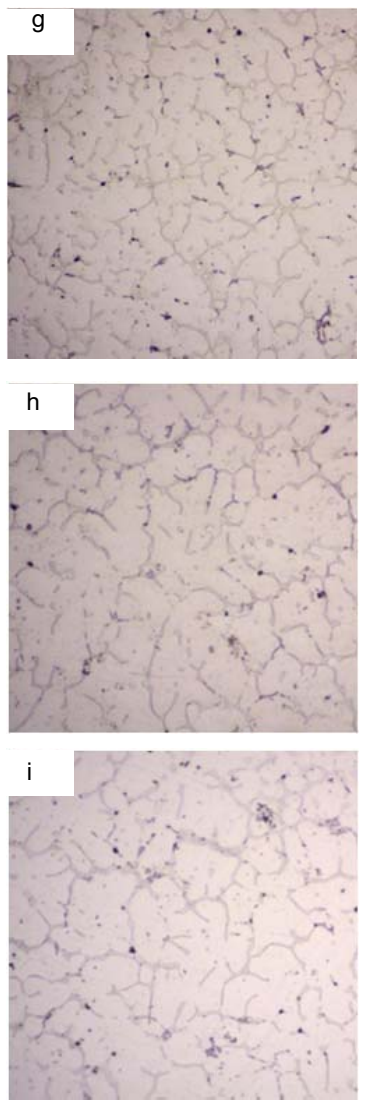

0.25 wt. $\%$ Ti
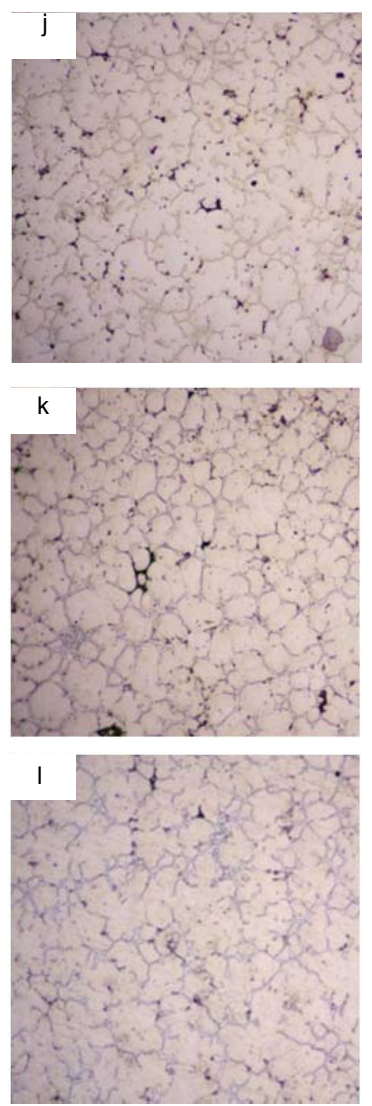

Fig. 6. Microstructure of Al-10Zn-6Mg alloy with: (a-c) 0, (d-f) 0.02, (g-i) 0.05, and (j-1) 0.25 wt. \% Ti at underaged (2 h), peakaged $(102 \mathrm{~h})$, and overaged $(200 \mathrm{~h})$ condition with ageing temperature of $130{ }^{\circ} \mathrm{C}$.
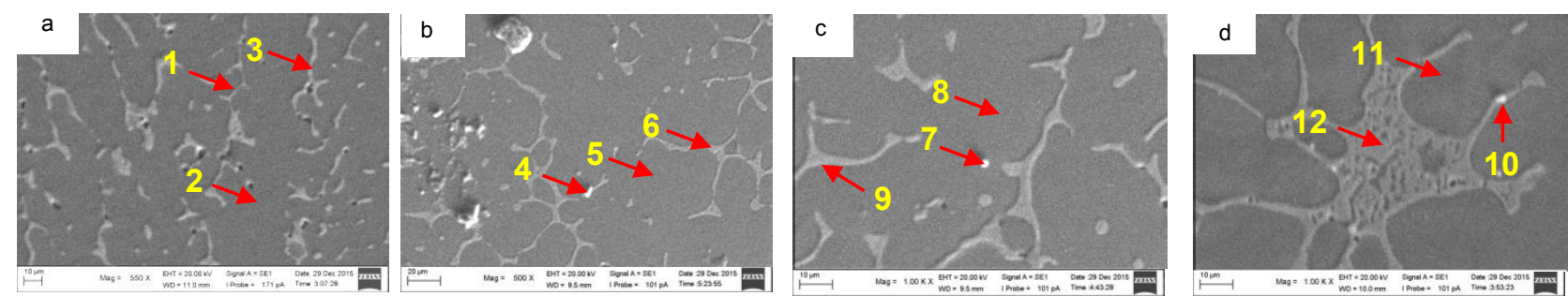

Fig. 7. SEM images of Al-10Zn-6Mg with addition of (a) 0 , (b) 0.02 , (c) 0.05 , and (d) 0.25 wt. \% Ti in peakaged condition.

Table 2. EDX characterization on Al-10Zn-6Mg-xTi

\begin{tabular}{|c|c|c|c|c|c|c|c|}
\hline \multirow{2}{*}{ Mark } & \multicolumn{6}{|c|}{ Element content (at. \%) } & \multirow{2}{*}{$\begin{array}{c}\text { Possible } \\
\text { phase }\end{array}$} \\
\hline & Al & Zn & Mg & $\mathbf{T i}$ & $\mathbf{C}$ & $\mathbf{O}$ & \\
\hline 1 & Bal & 12.65 & 15.9 & - & 18.8 & 3.63 & $\mathrm{Mg}_{12}(\mathrm{Al}, \mathrm{Zn})_{49}$ \\
\hline 2 & Bal & 1.72 & 5.13 & - & 15.9 & 2.67 & $\alpha-\mathrm{Al}$ \\
\hline 3 & Bal & 1.84 & 5.22 & - & 14.9 & 2.87 & $\mathrm{Al}_{8} \mathrm{Mg}_{5}$ \\
\hline 4 & $\mathrm{Bal}$ & 0.68 & 2.23 & 1.83 & 45.8 & 36.1 & $\mathrm{Mg}_{12}(\mathrm{Al}, \mathrm{Zn})_{49}$ \\
\hline 5 & Bal & - & 1.52 & 0.05 & 46.3 & 37.9 & $\alpha-\mathrm{Al}$ \\
\hline 6 & Bal & - & 1.15 & - & 49.4 & 36.3 & $\mathrm{Al}_{8} \mathrm{Mg}_{5}$ \\
\hline 7 & $\mathrm{Bal}$ & 0.10 & 4.41 & - & 39.4 & 20.6 & $\mathrm{Mg}_{12}(\mathrm{Al}, \mathrm{Zn})_{49}$ \\
\hline 8 & Bal & - & 2.69 & - & 47.6 & 24.4 & $\alpha-\mathrm{Al}$ \\
\hline 9 & Bal & - & 4.17 & - & 29.9 & 9.89 & $\mathrm{Al}_{8} \mathrm{Mg}_{5}$ \\
\hline 10 & Bal & 13.09 & 20.9 & - & 24.1 & 6.80 & $\mathrm{Mg}_{12}(\mathrm{Al}, \mathrm{Zn})_{49}$ \\
\hline 11 & $\mathrm{Bal}$ & - & 4.24 & - & 29.5 & 13.3 & $\alpha-\mathrm{Al}$ \\
\hline 12 & $\mathrm{Bal}$ & - & 8.96 & 0.06 & 31.9 & 47.7 & $\mathrm{Al}_{8} \mathrm{Mg}_{5}$ \\
\hline
\end{tabular}

Table 3. Phase formation and diffusion temperature of Al-10Zn-6Mg-xTi.

\begin{tabular}{cccc}
\hline \multirow{2}{*}{ wt. \% Ti } & \multicolumn{3}{c}{ Temperature $^{\circ} \mathbf{C}$} \\
\cline { 2 - 4 } & GP zone & $\boldsymbol{\eta}^{\prime}$ & $\boldsymbol{\eta}$ \\
\hline Formation & 40 & 120 & 200 \\
0.02 & 40 & 150 & 190 \\
0.05 & 40 & 120 & 210 \\
0.25 & 40 & 180 & 360 \\
Diffusion & & & \\
0 & 70 & 180 & 230 \\
0.02 & 100 & $160-180$ & 220 \\
0.05 & 100 & 140 & 240 \\
0.25 & 140 & 300 & 380 \\
\hline
\end{tabular}


a

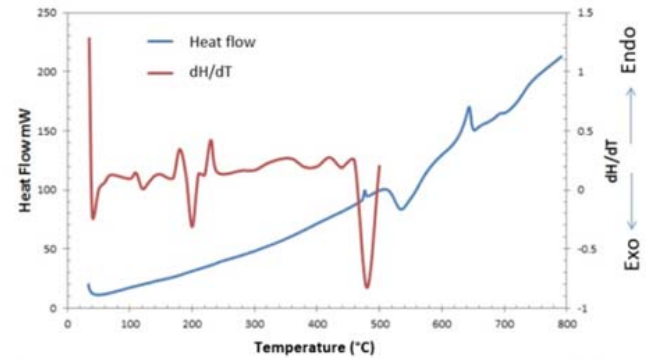

b

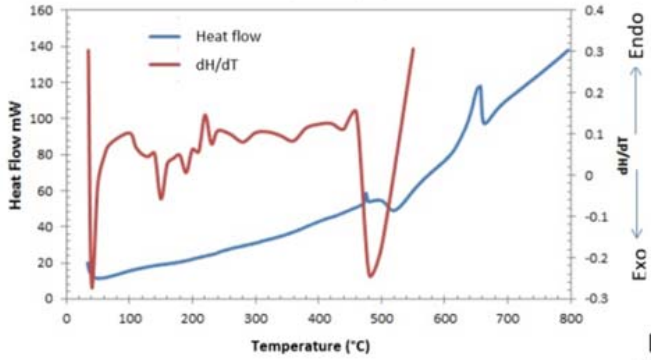

C

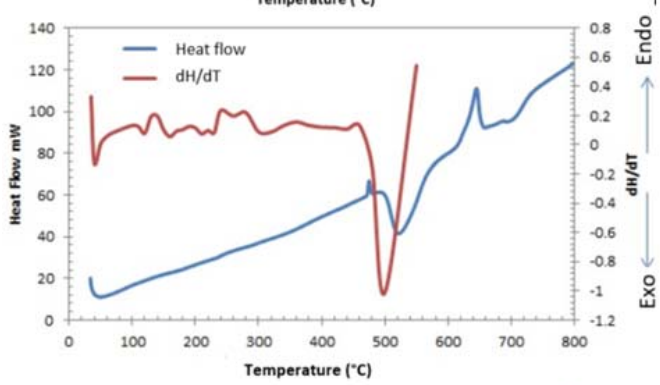

d

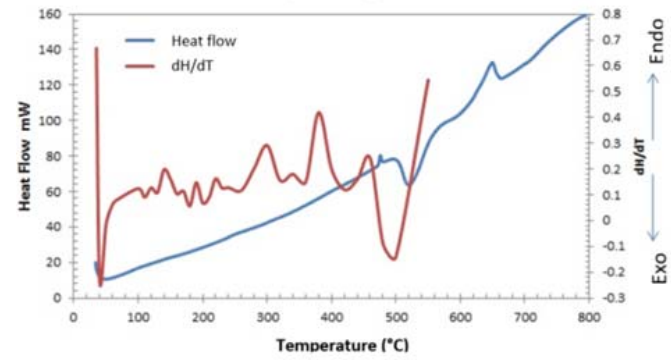

Fig. 8. Heat flow curves and their derivatives of Al-10Zn-6Mg with addition of (a) 0 , (b) 0.02 , (c) 0.05 , and (d) 0.25 wt. $\% \mathrm{Ti}$.

Results of STA analysis in this work showed that formation of GP zone, $\eta$ ', and $\eta$ occurred at $40{ }^{\circ} \mathrm{C}, 120$ $180{ }^{\circ} \mathrm{C}$, and $190-360{ }^{\circ} \mathrm{C}$, respectively. The diffusion of GP zone took place at $70-140{ }^{\circ} \mathrm{C}, \eta$ ' at $140-300{ }^{\circ} \mathrm{C}$, and $\eta$ at $220-380^{\circ} \mathrm{C}$. In addition, the heat flow curves showed two endothermic peaks. The first one was indicated as $\beta$ phase diffusion, which occurred at 476.67, 475.43, 475.25 , and $475.85{ }^{\circ} \mathrm{C}$ for alloy with $0,0.02,0.05$, and 0.25 wt. $\% \mathrm{Ti}$, respectively. $\beta$ phase was formed at 447 ${ }^{\circ} \mathrm{C}$. Additionally, the second endothermic peak presented the $\alpha$-Al phase diffusion for each alloy with $0,0.02,0.05$, and 0.25 wt. $\%$ Ti which were at $644.06,656.53,645.05$, and $649.23{ }^{\circ} \mathrm{C}$. It was lower than $660{ }^{\circ} \mathrm{C}$ due to alloying content which decreased the melting point of base metal. In summary, $\mathrm{Ti}$ addition gave no effect on the temperature of phase transformation.

\section{Conclusions}

This work investigated the microstructure, phase transformations, and mechanical properties of aged $\mathrm{Cu}$ -
$10 \mathrm{Zn}-6 \mathrm{Mg}$ alloys with addition of $0.02,0.05$, and 0.25 wt. \% Ti. Results are summarized as follows:

1. Addition of $0.02,0.05$, and 0.25 wt. $\%$ Ti increased the hardness of as-cast $\mathrm{Al}-10 \mathrm{Zn}-6 \mathrm{Mg}$ wt. \% alloys from 49.72 to $49.92,52.02$, and $53.08 \mathrm{HRB}$, simultaneous to the reduction of its SDAS value from 22.78 to $22.68,19.56$, and $16.55 \mu \mathrm{m}$ and a rise in GRF from 21 to $25.91,33.28$, and 82.4, respectively.

2. Ti did not contribute to the peak hardness of Al$10 \mathrm{Zn}-6 \mathrm{Mg}$ wt. $\%$ alloys which were found to be 86.1 $\mathrm{HRB}$ and 85.9, 85.1, and 84.4 $\mathrm{HRB}$ at 0.02 , 0.05 , and 0.25 wt. $\% \mathrm{Ti}$ additions, respectively, proportional to their impact numbers, ranging between $10-11 \mathrm{~kJ} / \mathrm{m}^{2}$.

3. Microstructural investigation on Al-10Zn-6Mg-xTi wt. \% alloys showed the presence of primary $\alpha$-Al matrix, spider web-shaped $\beta\left(\mathrm{Al}_{8} \mathrm{Mg}_{5}\right)$, and bright interdendritic $\mathrm{T}\left(\mathrm{Mg}_{32}(\mathrm{Al}, \mathrm{Zn})_{49}\right)$ phases.

4. Phase transformation during age hardening of Al$10 \mathrm{Zn}-6 \mathrm{Mg}$-xTi wt. \% alloys was identified as an exothermic formation of $\eta$ ' following the order of GP Zone $\rightarrow \eta \rightarrow \eta^{\prime}\left(\mathrm{MgZn}_{2}\right)$ and its endothermic diffusion. The formation of $\beta \quad\left(\mathrm{Al}_{8} \mathrm{Mg}_{5}\right)$ was observed at $447{ }^{\circ} \mathrm{C}$ while its diffusion occurred at approx. $475^{\circ} \mathrm{C}$.

\section{Acknowledgements}

This work was supported by Directorate of Research and Community Services, Universitas Indonesia through Hibah PITTA (Publikasi Internasional Terindeks untuk Tugas Akhir Mahasiswa) UI 2018.

\section{References}

1. M. Syahid, B.T. Sofyan, J. Adv. Mat. Res. 789, 324329 (2013)

2. F.H. Kurniawan, Pengaruh Penambahan 0.067, 0.081, dan 0.115 wt. \% Ti thd Karakteristik Paduan $A C 4 B$ Hasil LPDC (Undergrad. Thesis, Universitas Indonesia, 2008)

3. B.T. Sofyan, D.J. Kharistal, L. Trijati, K. Purba, R. Susanto, Mat. Des. 31, S-36-S43 (2010)

4. P.I. Lestari, Studi Pengaruh Penambahan TiB terhadap Karakteristik Komposit Al-10Zn-6Mg-3Si Berpenguat $\mathrm{ZrO}_{2}$ Hasil Squeeze Casting (Undergrad. Thesis, Universitas Indonesia, 2009)

5. G.K. Sigworthh, T.A. Kuhn, Grain Refinement of Aluminium Casting Alloys (AFS, 2007)

6. T. Gao, Y. Zhang, X. Liu, Mat. Sci.\&Eng. A 598, 293-298 (2014)

7. B.T. Sofyan, L. Basuki, Proc. $11^{\text {th }}$ Int. Conf. Quality in Research, 832-839 (2009)

8. B.T. Sofyan, Pengantar Material Teknik (Penerbit Salemba, 2009)

9. C.A. Grove, G. Judd, Met. Trans. 4, 1025 (1973) 
10. M. Murayama, K. Hono, Acta Mat. 47, 1537-1548 (1999)

11. S.K. Maloney, K. Hono, I.J. Polmear, S.P. Ringer, Scripta Mat. 41, 1031-1038 (1999)
12. V. Raghafan, J-Alloy Phase Diagrams. 28, 203-208 (2007)

13. K.G. Khrisna, K. Sivaprasad, K. Venkateswarlu, K.C.H. Kumar, J. Mat. Sci. Eng. 535, 129-135 (2012) 